\title{
Commercialising Technical Innovation: Role of Business Incubators in Kerala
}

Abraham TS*

Department of Commerce, Marthoma College for Women, Kerala, India

\begin{abstract}
Kerala Start up Mission (KSUM) is designed to provide a springboard to budding entrepreneurs who wish to launch themselves into the world of technology based business careers. Entrepreneurs' bright ideas to develop a product or service using advanced technology solutions can find a fertile ground in Kerala start-up Mission. Since start-up companies lack many resources, experience and networks, business incubators (Bls) provide a service which helps them get through initial hurdles in starting up a business. These hurdles include space, funding, legal, accounting, computer services and other prerequisites to running the business. The study focusses on the role of four Bls in Kerala. The significant finding is the remarkable role played by incubators in promoting entrepreneurship by commercialising technical innovations.
\end{abstract}

Keywords: Business incubators; Technology; External conditions; Internal conditions

\section{Introduction}

\section{Evolution of business incubators in international perspective}

In general, there are three main periods of business incubation evolution.

- First generation: Initiation and development of the concept (late 1950s-mid 1980s). We call it "Infrastructure: economies of scale" period.

- Second generation: Active growth and development (mid 1980s-mid 1990s). "Business support: accelerating the learning curve" is the name of that period.

- Third generation: Industry maturity and new leaps of development (mid 1990s-present). "Networks and Value Chains" are the most common characteristics of that period.

However, the date of its institutionalization where main components of basic business incubator model were linked together is 1959. The first business incubator (Batavia Industrial Centre) was opened in New York. Several ventures were launched, and this event is considered to be the first when the concept of business incubation was formalized. It became potential economic development tool for local, regional and country level policy makers and government. First generation of business incubators offered mostly affordable office space and shared resources Provision of shared physical space and shared administrative services was critical to business incubation and has been identified by tenants as the most beneficial feature of business incubators at that time.

Second generation of business incubators was on its peak when BIs became a popular economic development tool to promote the creation of new technology-intensive companies Agencies, governments gradually started to realize that innovation and entrepreneurship were becoming the cornerstones of economic development and growth. The first national study of business incubators was done in 1984.National Business Incubation Association (NBIA) was established in the USA in 1985 aiming to provide training and tools for assisting start-up and fledgling firms and to serve as a clearinghouse for information on incubator management and development issues. Business Incubation reached China with its first Wuhan business incubator in 1987. One year later the Torch Program by the Ministry of Science and
Technology was initiated in China in order to accelerate national technology development, commercialization and internationalization. First corporate business incubators appeared with initiative from City Venture Corporation (CVC), a Control Data division that developed business incubators in several large and small cities. Third generation gives us additional variable which is networking. There are several reasons of why networks became so important: technological achievements such as internet and recent IT trends allow business to solve issues in one day that could require years only 50 years ago (if you will add to this arguments such trends as Crowdsourcing and Crowdfunding, Gamification, Social Networks, Mobility, Collaboration tools, Cloud computing you will get a whole picture), Resource scarcity on the one hand and access to capital, expertise and knowledge on the other hand became very important in the knowledge-based economy. These are bottlenecks of start-ups nowadays that could be partly solved through networking models of business incubators.

\section{Number of business incubators world wide}

As of October 2012, there were over 1,250 incubators in the United States, up from only 12 in 1980. InBIA (International Business Innovation Association) estimates that there are about 7,000 business incubators worldwide. The incubation model has been adapted to meet a variety of needs, from fostering commercialization of university technologies to increasing employment in economically distressed communities to serving as an investment vehicle.

\section{Evolution of business incubators in national perspective}

Technology Business Incubators in India have existed since 1980s, under the Government of India and since late 1990s under the private industry. They have played a critical role in encouraging risk taking

*Corresponding author: Abraham TS, Assistant Professor, Department of Commerce, Marthoma College for Women, Kerala, India, Tel: 9447829754; E-mail: sherinsophia@gmail.com

Recieved September 30, 2017; Accepted October 31, 2017; Published November 08, 2017

Citation: Abraham TS (2017) Commercialising Technical Innovation: Role of Business Incubators in Kerala. J Entrepren Organiz Manag 6: 217. doi: 10.4172/2169-026X.1000217

Copyright: (C) 2017 Abraham TS. This is an open-access article distributed under the terms of the Creative Commons Attribution License, which permits unrestricted use, distribution, and reproduction in any medium, provided the original author and source are credited. 
and public research in the information technology industry. Their success led to a massive increase in the number of incubators being setup in the country, with over 300 registered incubators operating in the country as of early 2014. The Government of India under the aegis of Department of Science \& Technology provides for institutional mechanism for promoting knowledge-driven and technology-intensive enterprises. This is primarily situated under the National Science \& Technology Entrepreneurship Development Board (NSTEDB). The Board, having representations from socio-economic and scientific Ministries/Departments, aims to convert "job-seekers" into "job generators" through Science \& Technology (S\&T) interventions and programmes. The scheme for Science \& Technology Entrepreneurs Parks (STEP), which was started in the early 1980s, and the Technology Business Incubators (TBI) programme launched in early 2000, both of which have been fairly successful in increasing the number of startup companies engaging in innovation as well as fostering a conducive environment of risk taking while contributing to the regional and national economy.

\section{Start of business incubators in Kerala}

Kerala Start up Mission (KSUM): Kerala Start up Mission (KSUM) formerly known as 'Techno Park Technology Business Incubator' is India's first and successful Non Academic Business Incubator, hosted and housed inside Asia's Largest IT Park Techno park. Techno park Technology Business Incubator (T-TBI), a joint association of Techno Park, Thiruvananthapuram and the Department of Science and Technology (DST), Government of India, to help the technology business start-ups, started operation during 2007. KSUM functions with a vision to support and nurture the start-up in the state of Kerala. It also is the first non-academic business incubator. Since launching in 2006, KSUM has incubated more than 200+ of India's most promising start-ups. Kerala Start-up Mission has been actively initiating various programmes for developing the student entrepreneurship in the state. Government of Kerala declared the start-up policy with an aim to accelerate the growth of student entrepreneurs. KSUM being the nodal agency for implementing the Start-up policy have come up with various schemes for the effective implementation of the policy. The schemes cover a broad area from schools, colleges and to young entrepreneurs.

Statement of the problem: Business incubators can support new potential companies in their development process by giving them credibility, but also by helping them to build promising support and business networks. The main research question is how business incubators can support entrepreneurs, in their efforts to build up networks for the benefit of their own company, by focusing more on social capital. Over one lakh students graduate in engineering and nonengineering subjects in Kerala every year. Out of these, a significant number possess valuable entrepreneurial ideas, which however fail to see the light of day due to lack of necessary environment and support.

\section{Research questions?}

- Whether business incubators can support entrepreneurs, in their efforts to build up networks?

- Whether business incubators can support entrepreneurs to set up their research and development and business operations?

- In this context, how effective is the incubation process to be taken on confidence to commercialise a technically innovative idea?

\section{Objectives of the Study}

- To analyse the evolution and status of business incubators in Kerala.

- To study the prospects in business incubation process.

- To understand the level of satisfaction among graduated companies from TBIs and start up village of Kerala.

- To understand the Government of Kerala initiatives to promote technical entrepreneurship.

\section{Significance of the Study}

\section{Interdisciplinary relevance}

The proposed study aims at throwing light on the effectiveness of business incubators in fostering and nurturing technical entrepreneurs. The study also aims at understanding the prospects of such incubators in making positive contributions commercializing technical innovations. Thus the study is having profound interdisciplinary relevance as it draws inspiration from technology, finance, engineering and entrepreneurship.

\section{Review of research and development in the subject}

International status: The pervious and current literature has been proven the positive impact of business incubators goals. First goal: it is supporting regional development through job creation [1]. Second goal: Incubator generally aids in the growth of new ventures. Third goal: Incubators fosters technological innovation and industrial renewal [1].

National status: So far as the Indian scenario is concerned; the National Science and Technology Entrepreneurship Development Board (NSTEDB) launched the Science and Technology Entrepreneurs Parks (STEP) in the early 1980s, and the Technology Business Incubators (TBI) in the beginning of 2000. Our country has nearly 120 incubators and science parks which have nurtured over 1150 entrepreneurs up to 2008. NSTEDB has so far created 53 TBIs in collaboration with premier academic and research institutes with an investment of Rs 100 crores and the cumulative revenue generated by these incubated enterprises now stands at Rs 595 crores. Although no comprehensive study has been carried out to measure the impact of these mechanisms put together, the estimates are that all these incubators help to graduate about 500 enterprises every year and out of these, 60 per cent are technology based start-ups. The report of the Working Group on science and technology for small and medium scale enterprises for the Eleventh Five Year Plan (2007-2012) recommends that a total of 170 Technology Business Incubators and 50 Technology Innovation Centres should be set up with a total outlay of Rs. 1100 Crore. Though the origin of Incubation Centres in India is recent, they have played a significant role in promoting entrepreneurship which could be reviewed from the unique contribution of few Business Incubation Centres. But literature in national status available in this budding venture is limited.

\section{Methodology}

The present study is exploratory in nature and makes use of Primary and Secondary data.

\section{Scope of the Study}

The present study was aimed at making a study of the role of Business Incubators in commercializing technical innovation. 


\section{Universe of the Study}

The universe for the study includes all the incubates availing benefits from recognized Business Incubators in Kerala.

\section{Research Design}

The present study is exploratory in nature and makes use of Primary and Secondary data. Primary data was sourced through a structured questionnaire being administered to the sample respondents. Sample respondents included graduated entrepreneurs of TBI- Trivandrum and TBI- Calicut and companies in process of incubation in TBIs and Start up village of Kerala. Secondary data sources such as relevant books published in Entrepreneurship and technopreneurship, management practices, guidelines from the Government of India and Kerala, research articles published on research journals and other background journals furnished from libraries and Internet was probed into as part of the study.

\section{Sampling and sample size}

The study covered the state of Kerala. The study was conducted in Business incubators in Kerala which are TBI- Techno Park, Trivandrum, CET-TBI, NIT- TBI Calicut and Start up Village, Ernakulam.

Structured questionnaire was given to 163 Heads of Incubate Companies based on convenience and proximity of Principal Investigator. Out of which 108 was found complete. So the study has used the responses of 108 respondents from various Business Incubators in Kerala.

The Composition was as follows:

TBI- Techno Park, Trivandrum 35

CET-TBI-15

NIT- TBI Calicut- 17

Start Up Village, Ernakulam-41.

\section{Sources of Data}

The source of primary data was from the 108 respondents from 4 Business incubators of Kerala Secondary data were gathered from reports, relevant documents/websites maintained by the Incubators, various books and journals.

\section{Analysis and Interpretation}

The analysis was carried through simple statistical techniques such as percentage analysis, drawing of percentage for generalization, construction of the tables for tabulation. The data has been presented in the form of tables and diagrams with suitable description. The study analysed the following aspects:

- Identification and evaluation of the business opportunity.

- Development of a business plan.

- $\quad$ Resources required.

- Management of the enterprise.

\section{Limitation of the Study}

1. The result are got time bound, so opinion may differ over the period of time.

2. The data cannot be generalized to the entire population of respondents because the sample size is small i.e., only 108 members from entire state.

\section{Literature Review}

\section{Business incubation}

Prospects and Challenges, Mian [1] assesses the value-added contributions of university technology business incubators (UTBIs) to their new technology-based tenant firms. The business incubator is widely believed as providing a nurturing environment for new business start-ups. However, the role played by university relationships in supporting the development of new technology-based firms (NTBFs) has escaped systematic review in the US due to a lack of historical data. To fill this gap, this article presents empirical data on UTBIs by focusing on their value-added dimensions which include typical incubator services along with university-related inputs. Litchenstein and Lyons [2] propose implementing a new approach, called the entrepreneurial development system, for transforming community economies. They first lay out the specifications for the new paradigm, drawing distinctions between current practice and their proposal. They then describe the major components of their proposed enterprise development system; detail its benefits to entrepreneurs, service providers, and the community; and discuss challenges to its full-scale implementation. Rustam [3] outlines measures to build an innovation-based economy. One such measure identified is the establishment of technology business incubators to nurture nascent ventures by providing focused counselling and facilitation services together with smart workspace and shared office facilities. An incubator, often referred within a technology park and affiliated to a technical university or research institute, provides a platform for convergence of support in a synergistic system. The state, business, venture capital and community each have special roles to play in stimulating the venture creation process. Philips [4] found that technology business incubators have not had a high incidence of technology transfer despite the fact that many were established with that goal in mind. This finding implies the need to continue investigating the problems that hinder the technology transfer process, especially in light of the fact that most technology incubator programs state as their objective the transfer and commercialization of technology [5]. The incubation process is composed of three main steps, consisting of the entrance of the entrepreneur in the incubator; the development of the company's product and organization; and the 'graduation' of the company from the incubator, as soon as it is ready to compete and grow in the open market. The process is complex, and the incubator's success depends on its capacity to successfully implement it. Rustam [6] finds the business incubation centre (BIC) helps to tackle the obstacles faced by entrepreneurs and facilitates the venture creation process. The factors of success in venture creation can be expressed as five interlinked rings: public policy that stimulates entrepreneurial businesses and provides the business infrastructure; private sector partnerships for mentoring and marketing; knowledge base of learning and research; professional networking, national and global; and community involvement to promote entrepreneurism and cultural change. Rudy [7] warns against non-accurate evaluations of the impact of incubators if one does not take into account the different types of incubators. The paper focuses on the dynamic process of incubation and concludes by underlining the importance of close links between incubators and business angel's networks. Hackett and David [8] developed theory seeking to predict and explain how business incubators and the process of business incubation increase the likelihood that new ventures will survive the early stages of development. It conceptualizes the incubator as an entrepreneurial firm that sources and macro-manages the 
innovation process within emerging organizations, infusing these organizations with resources at various developmental stage-gates while containing the cost of their potential failure. Lois [9] suggests a model that improves our understanding of the role of incubators in the entrepreneurial process. Specifically, we focus on the impact of the services offered, namely infrastructure, coaching and networks, on the graduation rates of the respective incubators' tenants. The model is tested among three different types of incubators, for-profit, non-profit, university-based incubators. Based on our qualitative findings, we conclude that our initial model is ineffective, in the sense that it cannot fully explain the role of the incubators in facilitating entrepreneurship. Abduh [10] shows that a business incubation/incubator program is an enterprise development strategy, aimed at accelerating the process of formation, development, survivability and growth of new enterprises by providing those new enterprises (clients) with a wide range of business assistance including physical facilities, business counselling and networking. The incubator is the unit of analysis while incubation outcomes-measured in terms of incubate growth and financial performance at the time of incubator exit-provide indicators of success. The model of the incubation process and specification of the range of possible incubation outcomes offer implications for managerial practice and policy-making vis-à-vis incubator management and good entrepreneurial failure. Screening practices by European business incubators in 2003 and compare these results with the American incubators in the 1980s [11]. In the last phase an exploratory link between screening practices and performance, measured in terms of tenant failure, is established. Most incubators do not screen potential tenants on a balanced set of factors, but concentrate either on the characteristics of the tenant's market or on the characteristics of the tenant's management team. However, the study revealed the tenant survival rate is positively related to a more balanced screening profile. Todd and Javalgi [12] identify factors necessary for the expansion of the business, along with the challenges of overcoming the resource gaps identified. The importance of fostering entrepreneurship is presented. The current state of technology is then evaluated. The paper concludes with an assessment of challenges and implications for future expansion. Geetha [13] observed private software parks been established in different parts of India. Also, focuses on promotion of biotechnology (biotech) parks by government of India to encourage growth of this emerging sector. The biotech parks are still in their infancy with a few operating parks. There are several upcoming biotech parks in different Indian states with support from the respective state governments. The government of India continues to play an important role in establishing technology parks. Biotech-Information Technology (Bio-IT) park is the next type of park that the government is planning to promote. This article discusses the institutional history of these technology parks in India. Bulsara et al. [14] emphasize support activities to convert Techno-innovation to Techno Entrepreneurship by keeping main focus on Technology Business Incubation approach in India. A conceptual model to establish relationship between Techno Innovation and Techno Entrepreneurship is developed. And this will be substantiated by various Techno Innovation and Techno Entrepreneurship illustrations of real life. Here, the major focus is given to Technology Business Incubation approach to support and create Techno Entrepreneurship from Techno-innovation. The papers also show a research gap, in the context of India, in the area of Techno-entrepreneurship through Technology Business Incubation. Tiago Business Incubators of all generations offer similar support services, tenants in older generation Business Incubators make less use of the Business Incubators' service portfolio as a consequence of slack selection criteria and the absence of clearly defined exit policies. The results imply that older generation
Business Incubators should update their service portfolio while simultaneously imposing stricter selection criteria and introducing exit policies requiring for Business Incubators' managers, prospective tenants and policy makers. Lina [15] pioneering finance initiatives have been emerging recently to bridge this gap. This paper discusses these emerging alternative financing initiatives which are forming an innovation eco-system of support for inclusive innovation and social entrepreneurship. It highlights two instruments in particular that are used in conventional innovation support: business incubation and venture capital. Two case studies were undertaken in order to provide evidence on how such instruments can operate with a 'dual bottom line' in supporting inclusive innovation and social entrepreneurship. B-Schools have a significant role to play in the growth of India as a nation because they are the breeding grounds for future entrepreneurs [16]. They have the potential to develop not only winning personal qualities but also provide an opportunity to create employment for self and for others. Entrepreneurship, self-employment and enterprise creation provide a solution to the crises of both unemployment and under-employment. The B-Schools help in increasing knowledge base, by identifying opportunities, and by pointing out ways to overcome barriers imposed by ones environment. Lose and Tengeh [17] study included limited research participants to the business incubators on the database of a local organization that promotes small and medium enterprises (SMEs) development strategy and programmes in the Western Cape Province. All five business incubators on the database were deemed suitable for the study. The results indicated that an average of twenty-five entrepreneurs graduated from the incubation programme in the last five years. Furthermore, lack of sponsorship, production space, advanced technological facilities (prototype) and expansion to different areas were found to be among the challenges hindering incubators. Journal of Global Entrepreneurship Research. It takes a broader view of entrepreneurship development and goes beyond the conventional approach of treating entrepreneurship development as a synonym for start-up. The research also encompasses various interventions to promote entrepreneurship that emerge along the life cycles of firms which include pre-start-up, start-up, survival and growth. Additionally, this paper argues that entrepreneurship cannot be promoted in isolation and needs government's policy support to mature. Therefore, it highlights the policy framework in which entrepreneurship has germinated and grown in India. Christine [18] deliberates upon political rationales, reviews evaluation literatures, and delineates suggestions for the future of the incubation industry. The main conclusion is that technology-oriented business incubators should be run as private organisations without public funding.

1. Data analysis and interpretation.

A. Most popular channel of information on business incubator in Kerala (Table 1 and Figure 1).

Inference: Interaction with Friend/teachers/relatives Incubators very popular

1. (31\%) of respondents found interaction with Friend/teachers/ relatives helpful in associating with a Business Incubator. The other factor that act as referrals for BI and make it very popular is website (21\%) of BI, Interaction with KIED (18\%) and media (10\%).

2. Role of business incubators in commercialising technical innovation identification and evaluation of the business opportunity (Table 2).

Inference 
Citation: Abraham TS (2017) Commercialising Technical Innovation: Role of Business Incubators in Kerala. J Entrepren Organiz Manag 6: 217. doi: 10.4172/2169-026X.1000217

Page 5 of 10

\begin{tabular}{|c|c|c|}
\hline Source & Frequency & Percentage \\
\hline Bank & 12 & 11.11111 \\
\hline Chamber of commerce & 2 & 1.851852 \\
\hline Friend/teachers/relatives & 34 & 31.48148 \\
\hline Interaction with KIED & 20 & 18.51852 \\
\hline Newspaper/Magazine & 11 & 10.18519 \\
\hline Radio/Television & 0 & 0 \\
\hline Social media contacts & 5 & 4.62963 \\
\hline Website of the incubator & 23 & 21.2963 \\
\hline Your education institution & 0 & 0 \\
\hline Other(Recruitment agency) & 1 & 0.925926 \\
\hline Total & 108 & 100 \\
\hline
\end{tabular}

Table 1: Table showing sources of information on business incubator.

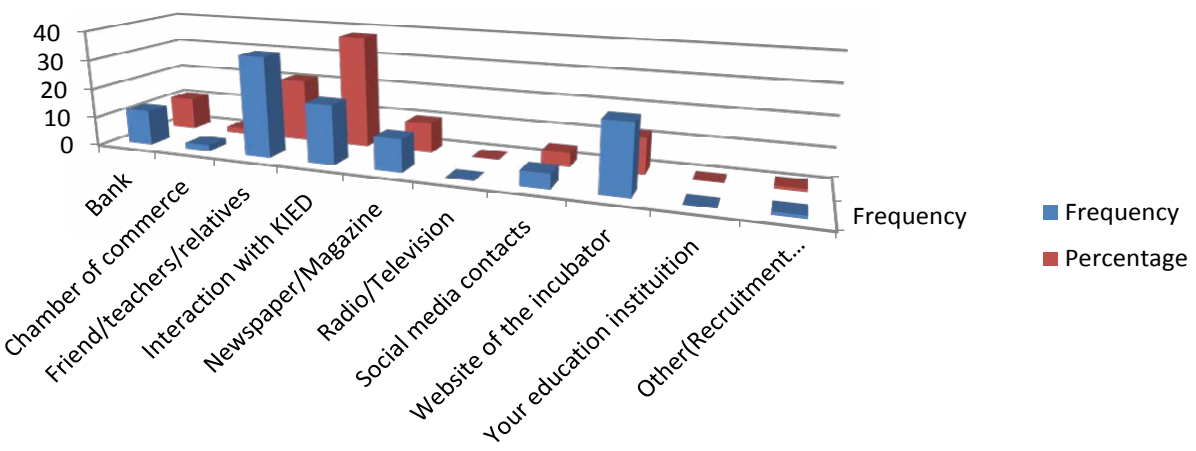

Figure 1: Diagram showing sources of information on business incubator.

1. $58 \%$ of respondents find incubators an advisory centre that provides idea on products or services.

2. $70 \%$ of respondents feel that Incubators assists in perceiving the value of business idea in terms of potential.

3. $56 \%$ of respondents feel that Incubators analyse the probable risks and returns of the proposed business.

4. $52 \%$ of respondents feel that Incubators understand the level of technical expertise required to implement the business idea.

5. $8 \%$ of respondents feel that Incubators directs the incubates to expert consultants to provide professional assistance whereas $39 \%$ remained neutral in this opinion.

6. $63 \%$ of respondents agree that Incubators helps in confirming the uniqueness of the business idea in its competitive environment.

7. $37 \%$ of respondents agree that Incubators are the reason that led to the opening of their firm.

8. $26 \%$ of respondents disagrees that Incubators suggests the resources required to convert the business idea into a feasible business venture.

It can be concluded that the role of business incubators in identification and evaluation of the business opportunity is high enough to promote entrepreneurship.

3. Development of a business plan (Table 3).

Inference

1. $45 \%$ of the respondents agree that business incubators help in formulating business plan.

2. $42 \%$ of the respondents agree that business incubators provide assistance in technical knowhow required for the firm.

3. $63 \%$ of the respondents agree that business incubators assist in the marketing efforts of the incubates.

4. $52 \%$ of the respondents agree that business incubators help in organizational planning.

5. $51 \%$ of the respondents agree that business incubators helps in networking with agencies like suppliers to procure resources.

6. $62 \%$ of the respondents agree that business incubators help in public relation efforts of the firm (obtaining governmental/legal approvals).

7. $54 \%$ of the respondents agree that business incubators help in the procurement of information relating to market, manufacturing operations or financial estimations.

It can be concluded that business incubators play a significant role in development of the business plan of an incubate company.

4. Resources required (Table 4).

Inference

1. $52 \%$ of the respondents agree that the incubator helps in identifying the resources required for materialising the business.

2. $62 \%$ of the respondents agree that the incubator provides the office space with a nominal rent.

3. $66 \%$ of the respondents commented that they are not aware that the incubator provides secretarial assistance.

4. $69 \%$ of the respondents agrees that the incubator library facilities in the premises of the business incubator. 
Citation: Abraham TS (2017) Commercialising Technical Innovation: Role of Business Incubators in Kerala. J Entrepren Organiz Manag 6: 217. doi: 10.4172/2169-026X.1000217

Page 6 of 10

\begin{tabular}{|c|c|c|c|c|}
\hline Aspects & Role of Business Incubators & Opinion & $\begin{array}{l}\text { Highest } \\
\text { Frequency }\end{array}$ & Percentage \\
\hline \multirow{40}{*}{$\begin{array}{l}\text { Identification and evaluation } \\
\text { of the business opportunity }\end{array}$} & \multirow{5}{*}{ Advisory center that provides idea on products or services } & Strongly disagree & 0 & 0 \\
\hline & & Disagree & 6 & 5.555556 \\
\hline & & Neutral & 13 & 12.03704 \\
\hline & & Agree & 26 & 24.07407 \\
\hline & & Strongly agree & 63 & 58.33333 \\
\hline & \multirow{5}{*}{$\begin{array}{l}\text { Assists in perceiving the value of business idea in terms } \\
\text { of potential }\end{array}$} & Strongly disagree & 0 & 0 \\
\hline & & Disagree & 1 & 0.925926 \\
\hline & & Neutral & 9 & 8.333333 \\
\hline & & Agree & 22 & 20.37037 \\
\hline & & Strongly agree & 76 & 70.37037 \\
\hline & \multirow{5}{*}{$\begin{array}{l}\text { Analyze the probable risks and returns of the proposed } \\
\text { business }\end{array}$} & Strongly disagree & 0 & 0 \\
\hline & & Disagree & 13 & 12.03704 \\
\hline & & Neutral & 23 & 21.2963 \\
\hline & & Agree & 61 & 56.48148 \\
\hline & & Strongly agree & 11 & 10.18519 \\
\hline & \multirow{5}{*}{$\begin{array}{l}\text { Understand the level of technical expertise required to } \\
\text { implement the business idea. }\end{array}$} & Strongly disagree & 0 & 0 \\
\hline & & Disagree & 5 & 4.62963 \\
\hline & & Neutral & 8 & 7.407407 \\
\hline & & Agree & 38 & 35.18519 \\
\hline & & Strongly agree & 57 & 52.77778 \\
\hline & \multirow{5}{*}{$\begin{array}{l}\text { Directs the incubates to expert consultants to provide } \\
\text { professional assistance }\end{array}$} & Strongly disagree & 2 & 1.851852 \\
\hline & & Disagree & 17 & 15.74074 \\
\hline & & Neutral & 43 & 39.81481 \\
\hline & & Agree & 37 & 34.25926 \\
\hline & & Strongly agree & 9 & 8.333333 \\
\hline & \multirow{5}{*}{$\begin{array}{l}\text { Helps in confirming the uniqueness of the business idea in } \\
\text { its competitive environment. }\end{array}$} & Strongly disagree & 0 & 0 \\
\hline & & Disagree & 5 & 4.62963 \\
\hline & & Neutral & 21 & 19.44444 \\
\hline & & Agree & 69 & 63.88889 \\
\hline & & Strongly agree & 13 & 12.03704 \\
\hline & \multirow[t]{5}{*}{ Reason that leads to the opening of firm. } & Strongly disagree & 17 & 15.74074 \\
\hline & & Disagree & 22 & 20.37037 \\
\hline & & Neutral & 27 & 25 \\
\hline & & Agree & 41 & 37.96296 \\
\hline & & Strongly agree & 1 & 0.925926 \\
\hline & \multirow{5}{*}{$\begin{array}{l}\text { Suggests the resources required to convert the business } \\
\text { idea into a feasible business venture }\end{array}$} & Strongly disagree & 18 & 16.66667 \\
\hline & & Disagree & 29 & 26.85185 \\
\hline & & Neutral & 21 & 19.44444 \\
\hline & & Agree & 28 & 25.92593 \\
\hline & & Strongly agree & 12 & 11.11111 \\
\hline
\end{tabular}

Table 2: Table showing opinion on role of $\mathrm{BI}$ in identification and evaluation of the business opportunity.

5. $48 \%$ of the respondents agrees that the incubator Laboratory facility is provided by the business incubator to the incubates.

1. $76 \%$ of the respondents agree that the incubator provides facilities like phone, fax, internet connection etc.

It can be concluded that the Incubator provides the necessary resources for the development and implementation of business idea. But in certain situations the facilities are not well communicated.

5. Management of the enterprise (Table 5).

Inference

1. $73 \%$ of the respondents agree that the incubator assists in identifying the various sources of financing available.

2. Of the respondents agrees that the incubator alerts or informs the various government grants available for incubates.
3. $31 \%$ of the respondents agree and $33 \%$ remained neutral in agreeing that the incubator provides training to acquire business skills.

4. $49 \%$ of the respondents agree that the incubator special assistance on business matters are offered for small scale firms.

5. $66 \%$ of the respondents remained neutral in agreeing that the incubator provides business counselling to face setbacks in business.

It can be concluded that business incubators helps incubates in managing their enterprise but such assistance are not well utilized by the incubates.

\section{Findings}

1. Interaction with Friend/teachers/relatives Incubators very popular.

1. $31 \%$ of respondents found interaction with Friend/teachers/ relatives helpful in associating with a Business Incubator. The other 
Citation: Abraham TS (2017) Commercialising Technical Innovation: Role of Business Incubators in Kerala. J Entrepren Organiz Manag 6: 217. doi: 10.4172/2169-026X.1000217

Page 7 of 10

\begin{tabular}{|c|c|c|c|c|}
\hline Aspects & Role of Business Incubators & Opinion & Highest Frequency & Percentage \\
\hline \multirow{35}{*}{$\begin{array}{l}\text { Development of a business } \\
\text { plan }\end{array}$} & \multirow[t]{5}{*}{ Helps in formulating business plan } & Strongly disagree & 7 & 6.481481 \\
\hline & & Disagree & 12 & 11.11111 \\
\hline & & Neutral & 18 & 16.66667 \\
\hline & & Agree & 22 & 20.37037 \\
\hline & & Strongly agree & 49 & 45.37037 \\
\hline & \multirow{5}{*}{$\begin{array}{l}\text { Provides assistance in technical knowhow } \\
\text { required for the firm }\end{array}$} & Strongly disagree & 6 & 5.555556 \\
\hline & & Disagree & 21 & 19.44444 \\
\hline & & Neutral & 7 & 6.481481 \\
\hline & & Agree & 28 & 25.92593 \\
\hline & & Strongly agree & 46 & 42.59259 \\
\hline & \multirow{5}{*}{$\begin{array}{l}\text { Assists in the marketing efforts of the } \\
\text { incubates }\end{array}$} & Strongly disagree & 0 & 0 \\
\hline & & Disagree & 1 & 0.925926 \\
\hline & & Neutral & 3 & 2.777778 \\
\hline & & Agree & 35 & 32.40741 \\
\hline & & Strongly agree & 69 & 63.88889 \\
\hline & \multirow[t]{5}{*}{ Helps in organizational planning } & Strongly disagree & 0 & 0 \\
\hline & & Disagree & 2 & 1.851852 \\
\hline & & Neutral & 6 & 5.555556 \\
\hline & & Agree & 43 & 39.81481 \\
\hline & & Strongly agree & 57 & 52.77778 \\
\hline & \multirow{5}{*}{$\begin{array}{l}\text { Helps in networking with agencies like } \\
\text { suppliers to procure resources }\end{array}$} & Strongly disagree & 0 & 0 \\
\hline & & Disagree & 2 & 1.851852 \\
\hline & & Neutral & 21 & 19.44444 \\
\hline & & Agree & 56 & 51.85185 \\
\hline & & Strongly agree & 29 & 26.85185 \\
\hline & \multirow{5}{*}{$\begin{array}{l}\text { Helps in public relation efforts of the firm } \\
\text { (obtaining governmental/legal approvals) }\end{array}$} & Strongly disagree & 3 & 2.777778 \\
\hline & & Disagree & 13 & 12.03704 \\
\hline & & Neutral & 23 & 21.2963 \\
\hline & & Agree & 67 & 62.03704 \\
\hline & & Strongly agree & 2 & 1.851852 \\
\hline & \multirow{5}{*}{$\begin{array}{l}\text { Helps in the procurement of information } \\
\text { relating to market, manufacturing } \\
\text { operations or financial estimations }\end{array}$} & Strongly disagree & 0 & 0 \\
\hline & & Disagree & 1 & 0.925926 \\
\hline & & Neutral & 9 & 8.333333 \\
\hline & & Agree & 39 & 36.11111 \\
\hline & & Strongly agree & 59 & 54.62963 \\
\hline
\end{tabular}

Table 3: Table showing role of $\mathrm{BI}$ in development of a business plan.

factors that act as referrals for BI and make it very popular is website (21\%) of BI, Interaction with KIED (18\%) and media (10\%).

2. $58 \%$ of respondents find incubators an advisory centre that provides idea on products or services.

3. $70 \%$ of respondents feel that Incubators assists in perceiving the value of business idea in terms of potential.

4. $56 \%$ of respondents feel that Incubators analyse the probable risks and returns of the proposed business

5. $52 \%$ of respondents feel that Incubators understand the level of technical expertise required to implement the business idea.

6. $8 \%$ of respondents feels that Incubators directs the incubates to expert consultants to provide professional assistance whereas $39 \%$ remained neutral in this opinion.

7. $63 \%$ of respondents agree that Incubators helps in confirming the uniqueness of the business idea in its competitive environment.

8. $37 \%$ of respondents agree that Incubators are the reason that led to the opening of their firm.

9. $26 \%$ of respondents disagrees that Incubators suggests the resources required to convert the business idea into a feasible business venture.

10. $45 \%$ of the respondents agree that business incubators help in formulating business plan.

11. $42 \%$ of the respondents agree that business incubators provide assistance in technical knowhow required for the firm.

12. $63 \%$ of the respondents agree that business incubators assist in the marketing efforts of the incubates.

13. $52 \%$ of the respondents agree that business incubators help in organizational planning.

14. $51 \%$ of the respondents agree that business incubators helps in networking with agencies like suppliers to procure resources.

15. $62 \%$ of the respondents agree that business incubators help in public relation efforts of the firm (obtaining governmental/legal approvals).

16. $54 \%$ of the respondents agree that business incubators help in the procurement of information relating to market, manufacturing operations or financial estimations. 
Citation: Abraham TS (2017) Commercialising Technical Innovation: Role of Business Incubators in Kerala. J Entrepren Organiz Manag 6: 217. doi: 10.4172/2169-026X.1000217

Page 8 of 10

\begin{tabular}{|c|c|c|c|c|}
\hline Aspects & Role of Business Incubators & Opinion & Highest Frequency & Percentage \\
\hline \multirow{28}{*}{ Resources required } & \multirow{5}{*}{$\begin{array}{l}\text { Helps in identifying the resources required } \\
\text { for materializing the business }\end{array}$} & Strongly disagree & 0 & 0 \\
\hline & & Disagree & 4 & 3.703704 \\
\hline & & Neutral & 5 & 4.62963 \\
\hline & & Agree & 42 & 38.88889 \\
\hline & & Strongly agree & 57 & 52.77778 \\
\hline & \multirow{5}{*}{$\begin{array}{l}\text { Provides the office space with a nominal } \\
\text { rent }\end{array}$} & Strongly disagree & 0 & 0 \\
\hline & & Disagree & 6 & 5.555556 \\
\hline & & Neutral & 3 & 2.777778 \\
\hline & & Agree & 31 & 28.7037 \\
\hline & & Strongly agree & 68 & 62.96296 \\
\hline & \multirow{3}{*}{$\begin{array}{l}\text { Provides secretarial assistance by the } \\
\text { business incubator }\end{array}$} & Yes & 37 & 34.25926 \\
\hline & & No & 5 & 4.62963 \\
\hline & & Don't Know & 66 & 61.11111 \\
\hline & \multirow{5}{*}{$\begin{array}{l}\text { Library facilities in the premises of the } \\
\text { business incubator }\end{array}$} & Strongly disagree & 7 & 6.481481 \\
\hline & & Disagree & 0 & 0 \\
\hline & & Neutral & 0 & 0 \\
\hline & & Agree & 32 & 29.62963 \\
\hline & & Strongly agree & 69 & 63.88889 \\
\hline & \multirow{5}{*}{$\begin{array}{l}\text { Laboratory facility is provided by the } \\
\text { business incubator to the incubates }\end{array}$} & Strongly disagree & 2 & 1.851852 \\
\hline & & Disagree & 8 & 7.407407 \\
\hline & & Neutral & 8 & 7.407407 \\
\hline & & Agree & 38 & 35.18519 \\
\hline & & Strongly agree & 52 & 48.14815 \\
\hline & \multirow{5}{*}{$\begin{array}{l}\text { Provides facilities like phone , fax , internet } \\
\text { connection etc. }\end{array}$} & Strongly disagree & 0 & 0 \\
\hline & & Disagree & 0 & 0 \\
\hline & & Neutral & 5 & 4.62963 \\
\hline & & Agree & 20 & 18.51852 \\
\hline & & Strongly agree & 83 & 76.85185 \\
\hline
\end{tabular}

Table 4: Table showing role of $\mathrm{BI}$ in procuring resources required.

\begin{tabular}{|c|c|c|c|c|}
\hline Aspects & Role of Business Incubators & Opinion & Highest Frequency & Percentage \\
\hline \multirow[t]{25}{*}{ Management of the enterprise } & \multirow{5}{*}{$\begin{array}{l}\text { Assists in identifying the various sources of } \\
\text { financing available }\end{array}$} & Strongly disagree & 0 & 0 \\
\hline & & Disagree & 9 & 8.333333 \\
\hline & & Neutral & 11 & 10.18519 \\
\hline & & Agree & 79 & 73.14815 \\
\hline & & Strongly agree & 9 & 8.333333 \\
\hline & \multirow{5}{*}{$\begin{array}{l}\text { Alerts or informs the various government } \\
\text { grants available for incubates }\end{array}$} & Strongly disagree & 0 & 0 \\
\hline & & Disagree & 3 & 2.777778 \\
\hline & & Neutral & 20 & 18.51852 \\
\hline & & Agree & 55 & 50.92593 \\
\hline & & Strongly agree & 30 & 27.77778 \\
\hline & \multirow[t]{5}{*}{ Provides training to acquire business skills } & Strongly disagree & 4 & 3.703704 \\
\hline & & Disagree & 2 & 1.851852 \\
\hline & & Neutral & 36 & 33.33333 \\
\hline & & Agree & 32 & 29.62963 \\
\hline & & Strongly agree & 34 & 31.48148 \\
\hline & \multirow{5}{*}{$\begin{array}{l}\text { Special assistance on business matters are } \\
\text { offered for small scale firms }\end{array}$} & Strongly disagree & 0 & 0 \\
\hline & & Disagree & 11 & 10.18519 \\
\hline & & Neutral & 32 & 29.62963 \\
\hline & & Agree & 53 & 49.07407 \\
\hline & & Strongly agree & 12 & 11.11111 \\
\hline & \multirow{5}{*}{$\begin{array}{l}\text { Provides business counselling to face } \\
\text { setbacks in business }\end{array}$} & Strongly disagree & 9 & 8.333333 \\
\hline & & Disagree & 6 & 5.555556 \\
\hline & & Neutral & 72 & 66.66667 \\
\hline & & Agree & 15 & 13.88889 \\
\hline & & Strongly agree & 6 & 5.555556 \\
\hline
\end{tabular}

Table 5: Table showing role of $\mathrm{BI}$ in managing the enterprise. 
17. $52 \%$ of the respondents agree that the incubator helps in identifying the resources required for materialising the business.

18. $62 \%$ of the respondents agree that the incubator provides the office space with a nominal rent.

19. $66 \%$ of the respondents commented that they are not aware that the incubator provides secretarial assistance.

20. $69 \%$ of the respondents agrees that the incubator library facilities in the premises of the business incubator.

21. $48 \%$ of the respondents agrees that the incubator Laboratory facility is provided by the business incubator to the incubates.

22. $76 \%$ of the respondents agree that the incubator provides facilities like phone, fax, internet connection etc.

23. $3 \%$ of the respondents agree that the incubator assists in identifying the various sources of financing available.

24. Of the respondents agrees that the incubator alerts or informs the various government grants available for incubates.

25. $31 \%$ of the respondents agree and $33 \%$ remained neutral in agreeing that the incubator provides training to acquire business skills.

26. $49 \%$ of the respondents agree that the incubator special assistance on business matters are offered for small scale firms.

27. $66 \%$ of the respondents remained neutral in agreeing that the incubator provides business counselling to face setbacks in business.

28. It can be concluded that business incubators helps incubates in managing their enterprise but such assistance are not well utilized by the incubates.

\section{Suggestions}

1. Business incubators can help determine and confirm market opportunities and help cultivate a plan to infiltrate those markets.

2. Incubator mentors can help with questions about licensing technologies as opposed to selling outright, pricing and revenue models and more.

3. A good incubator can help identify administrators, executives and strategists with whom one should be networking.

4. Business incubators can help entrepreneurs not just to start but expand business or to end a period of stagnation.

5. Effective incubators must be able to provide business counselling and management assistance to their client firms.

6. The value-added business services must enable the clients to differentiate from an office suite.

7. Incubators must be able to analyse the management capability of the entrepreneurs and assist in finding management for these companies.

8. When the entrepreneur is a technologist lacking business skills, an incubator can assist the owner in finding experts in the relevant field.

9. Self-appraisal or performance audit of Incubators is necessary.

10. Applying for an incubator can be a long process which must be reduced.

\section{Conclusion}

Though the origin of Incubation Centres in India is recent, they have played a significant role in promoting entrepreneurship which could be reviewed from the unique contribution of few Business Incubation Centres.

Not all business incubators are the same. Understanding what the incubator offers in terms of resources and services and costs and matching the needs and capabilities of start-up and start-up team is necessary.

Kerala Start-up Mission (KSUM) is designed to provide a springboard to budding entrepreneurs who wish to launch themselves into the world of technology based business careers. Entrepreneurs' bright ideas to develop a product or service using advanced technology solutions can find a fertile ground in Kerala Start-up Mission. KSUM is restricted to high tech start-ups with technology products and innovations.

Since start-up companies lack many resources, experience and networks, incubators provide services which helps them get through initial hurdles in starting up a business. These hurdles include space, funding, legal, accounting, computer services and other prerequisites to running the business.

Among the most common incubator services are: Help with business basics, Networking activities, Marketing assistance, Market Research, High-speed Internet access, Help with accounting/financial management, Access to bank loans, loan funds and guarantee programs, Help with presentation skills, Links to higher education resources, Links to strategic partners, Access to angel investors or venture capital, Comprehensive business training programs, Advisory boards and mentors, Management team identification, Help with business etiquette, Technology commercialization assistance and Help with regulatory compliance.

Business Incubators in Kerala is playing a significant role in commercializing technical innovation.

\section{References}

1. Mian SA (1996) Assessing Value-Added Contributions of University Technology Business Incubators to Tenant Firms. Research Policy 25: 325-335.

2. Litchenstein GA, Lyons TS (2001) The Entrepreneurial Development System Transforming Business Talent and Community Economies. Economic Development Quarterly.

3. Rustam L (2002) Technology Business Incubators to Help Build an InnovationBased Economy. Journal of Change Management 3: 167-176.

4. Philips RG (2002) Technology Business Incubators: How Effective as Technology Transfer Mechanisms? Technology in Society 24.

5. Elena A (2015) The Evolution of Startup Incubators - an Insider's View.

6. Rustam L (2003) Business Incubators in Developing Countries: Characteristics and Performance. International Journal of Entrepreneurship and Innovation Management 3: 31-55

7. Rudy A (2004) Incubators: Tool for Entrepreneurship? Small Business Economics 23: 127-135

8. Hackett SM, David MD (2004) A Real Options-Driven Theory of Business Incubation. The Journal of Technology Transfer 29: 41-54.

9. Lois $P$ (2004) The Journal of Technology Transfer. The Journal of Technology Transfer 29: 83-91.

10. Abduh M (2007) Investigating and Classifying Clients' Satisfaction with Business Incubator Services. 17.

11. Aerts K (2006) Critical Role and Screening Practices of European Business Incubators. Technovation 27: 254-267. 
Citation: Abraham TS (2017) Commercialising Technical Innovation: Role of Business Incubators in Kerala. J Entrepren Organiz Manag 6: 217. doi: 10.4172/2169-026X.1000217

Page 10 of 10

12. Todd PR, Javalgi RG (2007) Internationalization of SMEs in India: Fostering entrepreneurship by leveraging information technology. International Journal of Emerging Markets 2: 166-180.

13. Geetha V (2008) Technology Parks in a Developing Country: the Case of India The Journal of Technology Transfer 33: 285-299.

14. Bulsara H, Gandhi S, Porey PD (2009) Techno-Innovation to TechnoEntrepreneurship through Technology Business Incubation in India: An Exploratory Study. Asia Pacific Journal of Innovations and Entrepreneurship, Asian Association of Business Incubation 3: 55-77.

15. Lina S (2012) Innovative Initiatives Supporting Inclusive Innovation in India: Social Business Incubation and Micro Venture Capital. Technological
Forecasting and Social Change 79: 638-647.

16. Rehman AU, Elahi YA (2012) Entrepreneurship Education in India - Scope Challenges and Role of $B$ schools in Promoting Entrepreneurship Education. International Journal of Engineering and Management Research 2: 5-14.

17. Lose T, Tengeh R (2015) The Sustainability and Challenges of Business Incubators in the Western Cape Province, South Africa. Sustainability 7: 14344-14357.

18. Christine T (2007) Rethinking Technology-Oriented Business Incubators Developing a Robust Policy Instrument for Entrepreneurship, Innovation, and Regional Development? Growth and Change- A Journal of Urban and Regional Policy 38: 460-473. 